\title{
Knowledge of HIV and Safety Sexual Practices among Adolescent Girls in Benin City, Nigeria
}

\author{
K. A. Digban ${ }^{*}$, V. Aigbogun'1, 0. Agofure ${ }^{2}$ \\ ${ }^{1}$ Department of Public and Community Health, College of Health Sciences, Novena University, Ogume, \\ Nigeria \\ ${ }^{2}$ Department of Health Promotion and Education, Faculty of Public Health, University of Ibadan, Ibadan, Nigeria \\ Email: ${ }^{*}$ kadigban@yahoo.com
}

Received 23 April 2014; revised 23 May 2014; accepted 23 June 2014

Copyright (C) 2014 by authors and Scientific Research Publishing Inc.

This work is licensed under the Creative Commons Attribution International License (CC BY). http://creativecommons.org/licenses/by/4.0/

(c) (i) Open Access

\begin{abstract}
Adolescence is a time of emotional, physical and psychological development and contributes substantially to the well being of the individual in adulthood. Consequently, understanding their social and reproductive behaviour is of tremendous policy importance. This study was designed to investigate HIV knowledge and safety sexual practices among adolescent girls in Benin-city, Edo State, Nigeria. Methods: A cross sectional study was conducted among 100 randomly selected female students in SS1 and 2 from two secondary schools in Benin-city. A semi structured questionnaire was self administered to obtain information on respondents' socio-demographic characteristics, knowledge of HIV and safety practices. A 10-point knowledge scale graded, $<5$ and $\geq 6$ as poor and good knowledge respectively, was used to measure knowledge of HIV; while a 5-point practice scale graded $<2$ and $\geq 3$ was used as unsatisfactory and satisfactory safety sexual practices on HIV prevention respectively. Descriptive statistics, chi-square test and logistic regression were used to analyse the data with level of significance set at 0.05 . Results: The mean age of respondents was $12.70 \pm 1.2$ years, $50.0 \%$ were in SS2 and $65.0 \%$ had been in Benin-city from birth. The overall mean knowledge score of respondents was $14.70 \pm 4.43$ with $60.0 \%, 20.0 \%, 40.0 \%$ and $70.0 \%$ having good knowledge on perinatal/vertical transmission, sexual and parenteral transmission, epidemiological factors and preventive measures respectively. Misconceptions about HIV transmission include: HIV cannot be transmitted through oral sex, HIV can be transmitted by mosquitoes and naked eyes can detect who is infected. In addition, there was a significant difference between class of respondents and their general knowledge of HIV $(P<0.05)$. Respondents in SS2 were more likely to have good knowledge of HIV than their SS1 counterpart (OR $=3.4395 \%$ CI $=1.461$ - 8.057). Furthermore, respondents whose mothers attained at least secondary school are more likely to exhibit satisfactory safety sexual practices on HIV prevention than their counter-
\end{abstract}

\footnotetext{
${ }^{*}$ Corresponding author.

How to cite this paper: Digban, K.A., Aigbogun, V. and Agofure, O. (2014) Knowledge of HIV and Safety Sexual Practices among Adolescent Girls in Benin City, Nigeria. Open Journal of Clinical Diagnostics, 4, 137-144. 
part whose mothers had no formal education $(\mathrm{OR}=2.6795 \% \mathrm{CI}=0.619$ - 11.493). Conclusions: There were knowledge deficiencies in sexual and parenteral transmission, epidemiological factors of HIV as well as some misconceptions about the transmission of the HIV virus. Therefore, more awareness and health education interventions are needed at the post primary level to curb the spread of the virus.

\section{Keywords}

\section{Knowledge of HIV, HIV Transmission, Safety Practices}

\section{Introduction}

Acquired Immune Deficiency Syndrome (AIDS) is a pattern of overwhelming infections caused by the Human Immunodeficiency Virus (HIV), which attacks and destroys certain white blood cells that are essential to the body's immune system. According to UNAIDS [1], more than $70 \%$ of people who have contacted HIV live in sub-Saharan African. Nigeria has entered a stage where the epidemic could increase at an exponential rate unless adequate national and regional responses are mounted to stem the spread of HIV/AIDS [2]. HIV/AIDS and other sexually transmitted diseases are having devastating effects on the health of young people, particularly girls and young women. According to Kaiser Family Foundation [3], teens and young adults are in the centre of the epidemic because young people aging 15 - 24 account for approximately half of new adult HIV/AIDS infections and $28 \%$ of the global total adults living with HIV/AIDS. Similarly, United Nations Population Fund [4]; confirmed that young people are at the centre of the HIV/AIDS epidemic in terms of rates of infection, vulnerability and of the 1.5 billion young people worldwide, 11.8 million are estimated to be living with HIV. In an attempt to stem the tide of HIV infection, there is a need to educate people, most especially adolescents who are very sexually active.

The adolescent period is a time of exploration and experimentation during which internal conflict caused by hormonal changes, the influence of peer group, and the attitude and practices of significant adults in their lives such as teachers and parents, societal pressure, norms and values and economic situations all contribute to mould the character and behavioural patterns that are carried onto adulthood [5]. They are a high-risk group, more likely to be engaged in risky sexual and drug-use behaviour, with reduced feelings of vulnerability to disease, and oftentimes, a denial of any chance of infection; and less likely to have adequate knowledge of AIDS or other sexually transmitted diseases.

Knowledge about the spread of HIV and safe sexual practices has a critical impact on the prevention of AIDS. Adegbola, et al. [6] define knowledge as essentially the recall recognition of specific and universal elements in a subject area. In the context of HIV/AIDS, having knowledge implies ability to recall facts concerning causes, transmission, prevention, concerning HIV/AIDS. The level of accurate knowledge adolescents have about the cause and nature of HIV/AIDS, the methods of spread and the preventive measures will greatly influence their attitude towards the disease entity itself and people living with it, as well as result in a change in their sexual behaviours in favour of abstinence or at least a lower practise of unsafe sex. Thus, it is expected that when one has the knowledge of HIV/AIDS, the accompanying behaviour would be logical. That is having the knowledge of prevention, transmission and other facts would motivate logical safe sex behaviour. In relation to HIV/AIDS, the possibility that the possession of adequate and correct knowledge is highly correlated to preventive efforts is a strong motivating factor in most educational projects since it is assumed that knowledge will help to overcome fear, denial and also contribute to behaviour modification.

Consequently, in a study by Goya, [7], he found the most interesting characteristic among Indian sexually active girls were misconceptions about sex, sexuality and sexual health. Adolescents having sex relationships were somewhat better informed about the sources of spread of STDs and HIV/AIDS. He states that while $40.0 \%$ of sexually active girls were aware that condoms could help prevent the spread of HIV/AIDS and reduce the likelihood of pregnancy, only $10.5 \%$ used a condom during the last time they had intercourse. Furthermore, Ben-Zur et al. [8], in his study among Ethiopian immigrants in Israel, found out adolescents demonstrated a certain amount of knowledge regarding contraception and the risks of getting pregnant or contracting HIV through un- 
protected sex. The analyses of his results indicate that there is a considerable discrepancy between adolescents' knowledge and their sexual behaviour. In addition, Tobin and Okojie [9], in their study, among adolescents' discovered awareness and indeed general knowledge about the AIDS virus, modes of transmission and prevention of the disease were good, however, a greater proportion of the sexually active adolescents practiced unsafe sex.

This study was therefore designed to investigate the HIV knowledge and safety sexual practices among adolescent girls in Benin City, Nigeria.

\section{Materials and Methods}

The study was carried out in Oredo and Egor local government areas of Edo state in Nigeria. Oredo is a local government area of Edo State, Nigeria and its headquarter is Benin City. It has an area of $249 \mathrm{~km}^{2}$ and a population of 374,671 at the 2009 census. The people are predominantly farmers, but are also employed in a wide variety of white-collar jobs.

Similarly, Egor local government area of Edo State, Nigeria has its headquarters in the town of Uselu. It has an area of $93 \mathrm{~km}^{2}$ and a population of 339,899 at the 2006 census. The people are mainly farmers.

A descriptive cross sectional study design was used.

Study population was made up of female adolescents enrolled in senior secondary class of SSI and II of two secondary schools, one from each local government area. Thus, Idia College, Iyaro, located at Oredo local government area and University Demonstration Secondary School (UDSS], Uniben, Ugbowo, located at Egor local government area were randomly selected from a sample frame of list of government schools in both local government area.

A sample of student from senior secondary I and II were used for the study. In the selected schools, 25 respondents each from SSI and II were randomly selected from the class list in Idia College which is a homogenous female school, while 25 respondents each from SSI and II were randomly selected from the class list after they had been stratified by sex in the University Demonstration Secondary School. On the whole 100 questionnaires were administered.

Informed consent was obtained from the participants and Institutional Ethical Clearance was obtained before the study was conducted.

Data were collected using a self administered questionnaire focusing on knowledge of HIV and safety sexual practices of the students.

Cronbach Alpha test reliability was used to determine the reliability of the instrument. The Cronbach Apha Reliability statistics gave 0.983 .

The level of general knowledge of HIV was measured by a 10-point knowledge scale graded; Poor $\leq 5$ and Good $>5$, while the overall knowledge was measured by a 27-point knowledge scale graded; Poor $\leq 13$ and Good > 13. Similarly, respondents' level of HIV safety practices was measured by a 5-point practice scale graded; unsatisfactory $\leq 2$ and satisfactory $>2$.

Data generated were analysed using SPSS version 17.0. Descriptive statistics were used to evaluate frequency distribution, while chi-square test and logistic regression were performed to test for association between variables of interest with level of significance set at $\mathrm{P}<0.05$.

\section{Results}

A total of hundred students participated in the study. Mean age of respondents was $12.70 \pm 1.2$ years. Fifty (50.0\%) were from SS2 class and sixty-five (65.0\%) had been leaving in Benin-city from birth. Overall mean knowledge score of respondents was $14.7 \pm 4.4$, while mean safety practice score was $3.8 \pm 1.6$ (Table 1 ).

Results in the table below (Table 2) shows that fifty-five (55.0\%) of respondents were affirmative that a baby can become infected with HIV through breastfeeding, while sixty (60.0\%) were positive that an HIV infected pregnant woman can pass the virus to her unborn baby and HIV women can take medicines to reduce the chances of their babies being born with HIV respectively.

As shown in the results in Table 3, above two third 60 (60.0\%) of the respondents retorted that oral sex cannot transmit HIV, majority $80(80.0 \%)$ that sterile syringes cannot transmit HIV and seventy of the respondents 70 (70.0\%) answered that washing and douching the vagina prevents HIV.

Almost two third 65 (65.0\%) of respondents believes HIV can be transmitted by mosquitoes while majority 
Table 1. Socio-demographic variables of respondents.

\begin{tabular}{|c|c|c|c|c|}
\hline Variables & Frequency $(n=100)$ & Percentage & Overall knowledge & Safety practices \\
\hline Ages 9 - 10 & 1 & 1.0 & \multirow{4}{*}{$0.214^{*} \mathrm{NS}$} & \multirow{4}{*}{$0.128^{*} \mathrm{NS}$} \\
\hline $11-12$ & 48 & 48.0 & & \\
\hline $13-14$ & 42 & 42.0 & & \\
\hline $15-16$ & 9 & 9.0 & & \\
\hline Class SS1 & 50 & 50.0 & \multirow{2}{*}{$0.221^{*} \mathrm{NS}$} & \multirow{2}{*}{$0.617^{*} \mathrm{NS}$} \\
\hline SS2 & 50 & 50.0 & & \\
\hline \multicolumn{5}{|c|}{ How long have you been in Benin City } \\
\hline From birth & 65 & 65.0 & \multirow{4}{*}{$0.116^{*} \mathrm{NS}$} & \multirow{4}{*}{$0.040^{*} \mathrm{~S}$} \\
\hline $1-3$ years & 6 & 6.0 & & \\
\hline $4-6$ years & 10 & 10.0 & & \\
\hline$>6$ years & 19 & 19.0 & & \\
\hline \multicolumn{5}{|l|}{ Fathers level of edu. } \\
\hline No formal edu. & 15 & 15.0 & \multirow{4}{*}{$0.000^{*} \mathrm{~S}$} & \multirow{4}{*}{$0.916^{*} \mathrm{NS}$} \\
\hline Primary edu. & 20 & 20.0 & & \\
\hline Secondary edu. & 37 & 37.0 & & \\
\hline Tertiary edu. & 28 & 28.0 & & \\
\hline \multicolumn{5}{|l|}{ Mothers level of edu. } \\
\hline No formal edu. & 13 & 13.0 & \multirow{4}{*}{$0.591^{*} \mathrm{NS}$} & \multirow{4}{*}{$0.011^{*} \mathrm{~S}$} \\
\hline Primary edu. & 27 & 27.0 & & \\
\hline Secondary edu. & 42 & 42.0 & & \\
\hline Tertiary edu. & 18 & 18.0 & & \\
\hline \multicolumn{5}{|l|}{ Fathers occupation } \\
\hline Civil servant & 33 & 33.0 & \multirow{3}{*}{$0.995^{*} \mathrm{NS}$} & \multirow{3}{*}{$0.065^{*} \mathrm{NS}$} \\
\hline Artisan & 37 & 37.0 & & \\
\hline Businessman & 30 & 30.0 & & \\
\hline \multicolumn{5}{|l|}{ Mothers occupation } \\
\hline Civil servant & 18 & 18.0 & \multirow{4}{*}{$0.04^{*} \mathrm{~S}$} & \multirow{4}{*}{$0.080^{*} \mathrm{NS}$} \\
\hline Artisan & 28 & 28.0 & & \\
\hline Trader & 38 & 38.0 & & \\
\hline Businessman & 16 & 16.0 & & \\
\hline
\end{tabular}

NS-Not significant; S-Significant; "P-value.

Table 2. Knowledge of respondents on perinatal/vertical transmission.

\begin{tabular}{|c|c|c|}
\hline Variable & True & False \\
\hline A baby can become infected with HIV through breastfeeding & $55(55.0 \%)$ & $45(45.0 \%)$ \\
\hline An HIV infected pregnant woman can pass the virus to her unborn baby & $60(60.0 \%)$ & $40(40.0 \%)$ \\
\hline $\begin{array}{l}\text { HIV positive women can take medicines to reduce the } \\
\text { chances of their babies being born with HIV }\end{array}$ & $60(60.0 \%)$ & $40(40.0 \%)$ \\
\hline
\end{tabular}

Table 3. Knowledge of respondents on sexual and parenteral transmission.

\begin{tabular}{|c|c|c|}
\hline Variable & True & False \\
\hline Oral sex can transmit HIV & $40(40.0 \%)$ & $60(60.0 \%)$ \\
\hline Sterile syringes can transmit HIV & $20(20.0 \%)$ & $80(80.0 \%)$ \\
\hline Only persons who engage in risky behaviours can become infected with HIV & $70(70.0 \%)$ & $30(30.0 \%)$ \\
\hline Washing and douching the vagina prevents HIV & $70(70.0 \%)$ & $30(30.0 \%)$ \\
\hline
\end{tabular}


70 (70.0\%) of respondents disagreed that sexually active females are more prone to contacting HIV compared to sexually active males and sixty 60 (60.0\%) of the respondents retorted that HIV attacks the immune system and makes one vulnerable to other infections (Table 4).

Majority $90(90.0 \%)$ of respondents truly answered that only a blood test can confirm HIV infection, while almost half 45 (45.0\%) of respondents retorted that there are different strains of HIV. In addition, more than half $55(55.0 \%)$ of the respondents disagreed that there are different strains of HIV, while more than one third 40 (40.0\%) of the respondents says naked eyes can detect who is infected with HIV (Table 5).

As shown in Table 6, majority 80 (80.0\%) of the respondents agreed that birth control pills cannot prevent HIV, more than two third 70 (70.0\%) abstinence prevents HIV infection while fifty five (55.0\%) disagreed that condoms cannot prevent HIV and being faithful to one partner prevents HIV infection as answered by forty (40.0\%) of respondents.

Table 4. Knowledge of respondents on epidemiological factors of HIV.

\begin{tabular}{|c|c|c|}
\hline Variable & True & False \\
\hline HIV attacks the immune system and makes one vulnerable to other infections & $60(60.0 \%)$ & $40(40.0 \%)$ \\
\hline AIDS virus cannot survive outside the body & $50(50.0 \%)$ & $50(50.0 \%)$ \\
\hline HIV can be transmitted by mosquitoes & $65(65.0 \%)$ & $35(35.0 \%)$ \\
\hline $\begin{array}{l}\text { Sexually active females are more prone to contacting HIV } \\
\text { compared to sexually active males }\end{array}$ & $30(30.0 \%)$ & $70(70.0 \%)$ \\
\hline Younger women have a greater risk of HIV transmission compared to older women & $40(40.0 \%)$ & $60(60.0 \%)$ \\
\hline
\end{tabular}

Table 5. General knowledge of respondents on HIV.

\begin{tabular}{ccc}
\hline Variable & True & False \\
\hline Married people can be infected with HIV & $80(80.0 \%)$ & $20(20.0 \%)$ \\
Only a blood test can confirm HIV infection & $90(90.0 \%)$ & $10(10.0 \%)$ \\
Fit and healthy persons can be infected with HIV & $75(75.0 \%)$ & $25(25.0 \%)$ \\
HIV cannot be contacted from toilet seats & $70(70.0 \%)$ & $30(30.0 \%)$ \\
There are different strains of HIV & $45(45.0 \%)$ & $55(55.0 \%)$ \\
Naked eyes can detect who is infected & $40(40.0 \%)$ & $60(60.0 \%)$ \\
HIV is not an STD & $20(20.0 \%)$ & $30(80.0 \%)$ \\
Good nutrition, healthiness and fitness prevent HIV & $30(30.0 \%)$ & $50(70.0 \%)$ \\
Sickness cannot infer HIV infection & $50.0 \%)$ & $48(50.0 \%)$ \\
HIV is a threat in Benin city & $52(52.0 \%)$ & \\
\hline
\end{tabular}

Table 6. Knowledge on preventive measures of HIV.

\begin{tabular}{|c|c|c|}
\hline Variable & True & False \\
\hline Birth control pills cannot prevent HIV & $80(80.0 \%)$ & $20(20.0 \%)$ \\
\hline People on HIV medicines cannot pass on the virus & $60(60.0 \%)$ & $40(40.0 \%)$ \\
\hline Condoms cannot prevent HIV & $45(45.0 \%)$ & $55(55.0 \%)$ \\
\hline Abstinence prevents HIV infection & $70(70.0 \%)$ & $30(30.0 \%)$ \\
\hline Not going through FGM prevents FGM infection & $65(65.0 \%)$ & $35(35.0 \%)$ \\
\hline Being faithful to one partner prevents HIV infection & $60(60.0 \%)$ & $40(40.0 \%)$ \\
\hline
\end{tabular}


Table 7 shows that forty (40.0\%) of respondents had shared sharp objects such as needles with their friends, forty (40.0\%) had watched pornographic films and five (5.0\%) had sex under the influence of alcohol.

\section{Hypotheses}

As shown in Table 8 there was a significant relationship between length of time in Benin-city and safety and sexual practices among respondents $(\mathrm{P}<0.004)$. Respondents who had lived in Benin between 1 - 3 years were less likely to exhibit satisfactory safety and sexual practices than their counterparts who had lived in Benin-city from birth (OR $=0.14095 \% \mathrm{CI}=0.024-0.818)$.

Similarly, there was a relationship between fathers level of education and respondents overall knowledge of HIV/AIDS ( $\mathrm{P}<0.000)$. Respondents whose fathers attained at least tertiary institution are more likely to demonstrate good knowledge of HIV than their counterparts whose fathers had no formal education (OR $=14.6795 \%$ $\mathrm{CI}=3.100-69.391)$.

Furthermore, there was a significant association between mothers occupation and overall knowledge of HIV/AIDS ( $\mathrm{P}<0.04)$. Respondents whose parents are artisan and traders are more likely to exhibit good knowledge of HIV/AIDS than their counterparts whose parents are businesswomen respectively (OR $=6.60095 \% \mathrm{CI}$ $=1.694$ - 25.711), $(\mathrm{OR}=3.77195 \% \mathrm{CI}=1.085$ - 13.108).

\section{Discussion}

Most of the respondents were between the ages of 11 and 12 years because this is usually the age group of adolescents that characterise classes SS1 and 2 in the study area.

Table 7. Safety and Sexual practices of respondents.

\begin{tabular}{|c|c|c|}
\hline Variable & Yes & No \\
\hline Ever shared sharp objects such as needles with friends & $40(40.0 \%)$ & $60(60.0 \%)$ \\
\hline Ever involved in alcohol and drug abuse & $10(10.0 \%)$ & $90(90.0 \%)$ \\
\hline Ever watched pornographic films & $40(40.0 \%)$ & $60(60.0 \%)$ \\
\hline Ever had unprotected sex & $20(20.0 \%)$ & $80(80.0 \%)$ \\
\hline Ever had sex under the influence of alcohol & $5(5.0 \%)$ & $95(95.0 \%)$ \\
\hline
\end{tabular}

Table 8. Logistic regression of socio-demographic characteristics and overall knowledge and Safety and sexual practices.

\begin{tabular}{|c|c|c|c|c|c|}
\hline \multirow[t]{2}{*}{ Variable } & \multirow[t]{2}{*}{ df } & \multirow[t]{2}{*}{ P-value } & \multirow[t]{2}{*}{ Odds Ratio } & \multicolumn{2}{|c|}{$95 \%$ CI } \\
\hline & & & & Lower & Upper \\
\hline \multicolumn{6}{|c|}{ How long have you been in Benin City } \\
\hline From birth $\left(\mathrm{r}^{*}\right)$ & 1 & 0.000 & 7.125 & - & - \\
\hline 1 - 3 years & 1 & 0.029 & 0.140 & 0.024 & 0.818 \\
\hline 4 - 6 years & 1 & 0.156 & 0.327 & 0.070 & 1.530 \\
\hline$>6$ years & 1 & 0.055 & 0.304 & 0.090 & 1.028 \\
\hline \multicolumn{6}{|l|}{ Fathers level of edu. } \\
\hline No formal edu.(r*) & 1 & 0.032 & 0.250 & - & - \\
\hline Primary edu. & 1 & 0.215 & 2.667 & 0.566 & 12.557 \\
\hline Secondary edu. & 1 & 0.001 & 10.800 & 2.512 & 46.432 \\
\hline Tertiary edu. & 1 & 0.001 & 14.667 & 3.100 & 69.391 \\
\hline \multicolumn{6}{|l|}{ Mothers occupation } \\
\hline Civil servant & 1 & 0.159 & 2.750 & 0.673 & 11.239 \\
\hline Artisan & 1 & 0.007 & 6.600 & 1.694 & 25.711 \\
\hline Trader & 1 & 0.037 & 3.771 & 1.085 & 13.108 \\
\hline Businessman( $\left.\mathrm{r}^{*}\right)$ & 1 & 0.144 & 0.455 & - & - \\
\hline
\end{tabular}

$\mathrm{r}^{*}$ means that particular group was used as a reference category. 
HIV may pass from an infected mother to her infant during breastfeeding. However, the risk of transmission is greater if the mother is newly infected or if she has already developed AIDS. Respondents in the study affirmed this fact and are similar to previous findings [2] [9].

Every single act of intercourse whether oral, anal or vaginal with an HIV-infected person exposes the uninfected partner to the risk of infection. However, the results show knowledge deficiencies in transmission through oral sex. This is contrary to the results of previous studies were respondents affirmed that HIV can be transmitted through all forms of sexual intercourse [9] [10].

Furthermore, there was knowledge deficiency in epidemiological factors of HIV such as transmission of HIV by mosquitoes and susceptibility or vulnerability of sexually active females to HIV as compared to sexually active males. This indicates that students need more information and education on the routes of transmission of HIV. Similar deficiencies in knowledge had been reported in other studies [10]-[12]. Generally, a woman is more vulnerable to HIV infection because a larger surface is exposed during sexual intercourse and semen contains higher concentration of HIV than vaginal or cervical fluids.

Most of the respondents had adequate knowledge of HIV, this can be pitched on the fact that there is gradually increasing awareness of HIV/AIDS [9] [13]. However, there was knowledge deficiency on the different strains of HIV.

In addition, knowledge on preventive measures of HIV such as birth control pills was also adequate. This is similar to previous findings [9] who reported adequate knowledge on HIV preventive measures.

Similarly, respondents whose parents attained tertiary education have more comprehensive knowledge of HIV/AIDS than their counterparts with no formal education; this is similar to previous findings where respondents demonstrated comprehensive knowledge of HIV/AIDS with increasing level of education [14] [15]. These justifies the fact that education is a key part of HIV/AIDS prevention programmes, thus governments at all levels, non-governmental organisations and donor agencies should incorporate right to education as part of their HIV/AIDS prevention programs.

Adequate safety and sexual practices were also demonstrated by respondents. This is similar to previous findings where respondents in Lao People's Democratic Republic demonstrated adequate sexual practices in not having sex under the influence of alcohol and using condom regularly during sexual intercourse [10].

\section{Conclusion}

The study shows knowledge deficiencies in sexual and parenteral transmission, epidemiological factors of HIV as well as some misconceptions about the transmission of the HIV virus. Therefore, more awareness and health education interventions are needed at the post primary level to curb the spread of the virus.

\section{References}

[1] United Nations Action on Aids Programme (1999) Reports on the Global HIV/AIDS Epidemic. Family Health International, Geneva.

[2] Odu, B.K. and Akanle, F.F. (2008) Knowledge of HIV/AIDS and Sexual Behaviour among the Youths in South West Nigeria. Humanity \& Social Sciences Journal, 3, 81-88.

[3] Kaiser Family Foundation (2005) The Global HIV/AIDS Epidemic. HIV/AIDS Policy Fact Sheet.

[4] United Nations Population Fund (2007) Preventing HIV Infection: Young People. Population Issues. UNFPA Website. Last Visited 1/26/2008.

[5] Fernadez, D.M., Figueroa, W.I., Gomez, M., Maysonet, J., Olivares, E.R. and Hunter, R.F. (2008) Changes in HIV/ AIDS Knowledge among Early Adolescents in Puerto Rico. Ethnicity and Disease, 18, 146-150.

[6] Adegbola, O., Babalola, O. and Oni, J. (1995) Sexual Net Working in against the Freetown the Background of AIDS Epidemics. Health Transition Review, 5, 81-110.

[7] Goya, R.S. (2007) Socio-Psychological Constructs of Premarital Sex Behaviour among Adolescent Girls in India. Princeton University, Princeton.

[8] Ben-Zur, H., Breznitz, S., Wardi, N. and Berzon, Y. (2000) Denial of HIV/AIDS and Preventive Behavior among Israeli Adolescents. Journal of Adolescence, 23, 157-174. http://dx.doi.org/10.1006/jado.2000.0305

[9] Tobin, E.A. and Okojie, H.O. (2010) Knowledge, Attitude and Practices of Adolescent Secondary School Students in Uvwie Local Government Area of Delta State to HIV/AIDS. 
[10] Thanavanh, B., Harun-Or-Rashid, Kasuya, H. and Sakamoto, J. (2013) Knowledge, Attitudes and Practices Regarding HIV/AIDS among Male High School Students in Lao People's Democratic Republic. Journal of the International AIDS Society, 16, 17387. http://dx.doi.org/10.7448/IAS.16.1.17387

[11] Mansoor, A.B., Fungladda, W., Kaewkungwal, J. and Wongwit, W. (2008) Gender Differences in KAP Related to HIV/AIDS among Freshmen in Afghan Universities. Southeast Asian Journal of Tropical Medicine and Public Health, 39, 404-418.

[12] Tan, X., Pan, J., Zhou, D., Wang, C. and Xie, C. (2007) HIV/AIDS Knowledge, Attitudes and Behaviours Assessment of Chinese Students: A Questionnaire Study. International Journal of Environmental Research and Public Health, 4, 248-253.

[13] Wagbatsoma, V.A. and Okojie, O.H. (2006) Knowledge of HIV/AIDS and Sexual Practices among Adolescents in Benin City, Nigeria. African Journal of Reproductive Health, 10, 76-83. http://dx.doi.org/10.2307/30032473

[14] Nigerian National Health Demographic Health Survey, 2008.

[15] Population Council, 2013. 
Scientific Research Publishing (SCIRP) is one of the largest Open Access journal publishers. It is currently publishing more than 200 open access, online, peer-reviewed journals covering a wide range of academic disciplines. SCIRP serves the worldwide academic communities and contributes to the progress and application of science with its publication.

Other selected journals from SCIRP are listed as below. Submit your manuscript to us via either submit@scirp.org or Online Submission Portal.
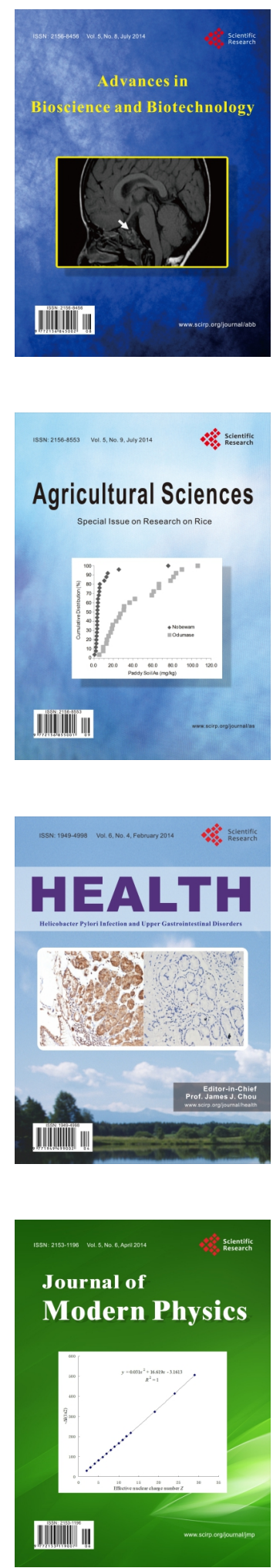
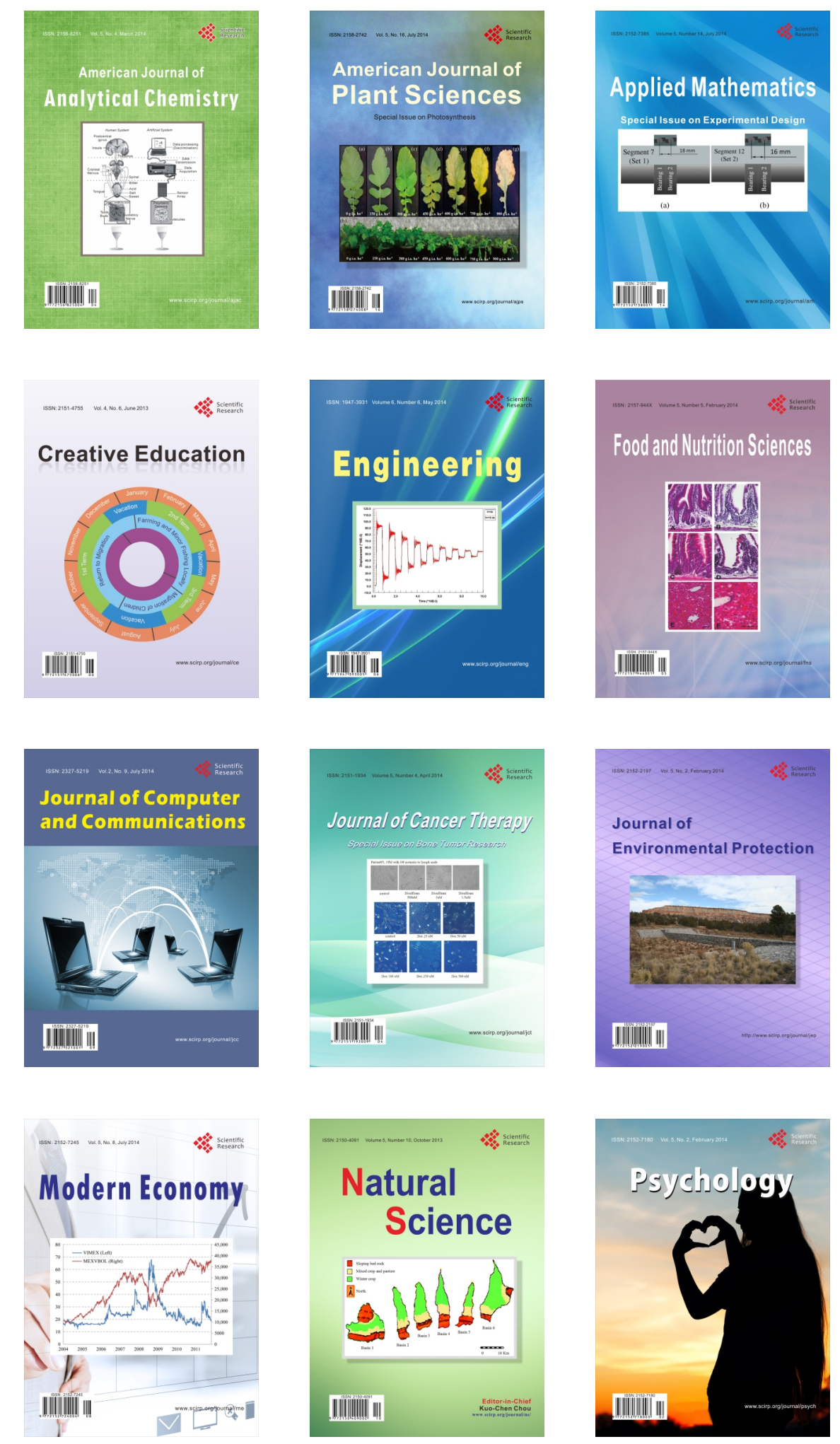